\title{
Performance of Gimmizah Cockerels Fed Two Levels of Methionine and Lysine and Two Levels of Protein
}

\author{
Alderey, A. A.; A. M. E. Nasr; H. A. Abu khashaba and H. R. Samak \\ Anim. Prod. Res. Inst. Agric. Res. Center, Egypt
}

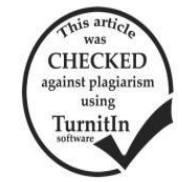

\section{ABSTRACT}

Seventy two cockerels of the 24-week-old Gimmizah strain were used to evaluate performance of Gimmizah cockerels fed two levels of methionine and lysine and two levels of protein. The work in this study was divided into two experiments. $1^{\text {st }}$ experiment aimed to test two levels of methionine at 0.24 and $0.34 \%$ with two levels 12 and $13 \% \mathrm{CP}$ while $2^{\text {nd }}$ experiment was designed to test levels of lysine at 0.60 and $0.70 \%$ at the same protein levels in factorial design $2 \times 2$ in each experiment. Body weight and feed intake were recorded while, the change in body weight, daily protein intake and methionine and lysine intake were calculated. Semen characteristics and some blood plasma characteristics were determined. The experimental period terminated at 40 weeks of age. The obtained results showed that: From results of the first experiment it will be noticed that protein levels had no significant effects on final body weight (FBW), BW change, daily feed intake, daily methionine intake, semen characteristics and fertility percentage but increasing protein level to 13\% CP exhibited significant increase in daily protein intake, globulin and AST in blood plasma. Increasing methionine level from $0.24 \%$ to $0.34 \%$ significantly improved FBW, BW change, daily feed intake, daily methionine intake, fertility percentage, globulin, glucose and semen quality characteristics except for volume which numerically improved. On the other hand daily protein intake, total protein, albumen, AST and ALT in blood plasma were not affected by methionine levels. Interaction effect between protein and methionine levels had significant effects. Cockerels fed diet $0.34 \%$ methionine with any protein level resulted in significant improvements in FBW, BW change, daily feed intake, methionine intake, motility\%, live sperm, dead sperm, abnormality, fertility percentage and glucose in blood plasma compared with methionine $0.24 \%$ level. Interaction between protein and methionine levels was not significant on semen volume, total protein, albumin and ALT in blood plasma. In the $2^{\text {nd }}$ experiment results revealed that daily lysine intake had insignificant effect on cockerels fed on different protein levels. In contrast cockerels fed diet contains $0.70 \%$ lysine displayed significant increases in daily lysine intake compared with those fed diet contains $0.60 \%$ lysine. Interaction between studied factors had insignificant affect FBW, BW change, all semen characteristics, fertility percentage, total protein, albumen and glucose in blood plasma but cockerels fed diet contains $0.60 \%$ lysine and $13 \% \mathrm{CP}$ content resulted in significant reduction $(\mathrm{P} \leq 0.05)$ in daily feed intake and lysine intake compared with other treatments. On the other hand cockerels fed diet containing $12 \% \mathrm{CP}$ with any lysine level recorded significant decrease in daily protein intake than those fed on $13 \% \mathrm{CP}$. While there were no significant variations in daily feed intake, daily lysine intake, AST and ALT in response to feeding on diets containing $0.70 \%$ lysine and 12 or $13 \%$ protein levels compared with other treatment groups. It can be concluded that the diets containing $13 \% \mathrm{CP}$ with $0.34 \%$ methionine or $0.60 \%$ lysine had not adverse effect on productive or reproductive performance of Gimmizah cockerels with taking into consideration semen quality and fertility percentage.

Keywords: Gimmizah cockerels, dietary protein, methionine, lysine levels, semen quality and some blood traits.

\section{INTRODUCTION}

Amino acid requirements of poultry are affected by many factors such as environment, genetic, sex and age moreover the diet protein content. Therefore it should be determined the amino acid requirements according to these factors. So it is now generally accepted that concept of the requirement for amino acids is proportionally linked to the requirement for the others.

Some producers feed cockerels the same diet throughout the production period, although they differ from the hen's nutritional needs. Increasing protein intake will increase BW of rooster and that can adverse affect on fertility percentage because more energy will be require supporting a greater BW and maintaining sperm production and mating activity (Romero-Sanchez et al., 2007). The use of specific diets during egg production for males has been shown to be beneficial in maintaining their physiological status and fertility. Many researchers (Harms and Ivey, 1992. and Harms and Russell 1995) as well as the NRC 1994 have specified a protein level at the requirement for methionine and lysine.

Recently, low dietary protein with synthetic amino acid supplementation is becoming closely related with feed formulation to reduce the nitrogen excretion and production cost (Chung et al., 1998).There is a little research directed to specific requirements for essential amino acids; therefore, a minimal amount of crude protein is generally planned to provide adequate amounts of essential amino acids whose needs are not sufficient known.

Generally methionine and lysine are considered the first and the second limiting amino acids in corn-soybean diets for laying hens (Liu et al., 2005). Many reports revealed that supplementation of methionine and lysine increased the protein efficiency utilization (Schutte et al., 1994; Novak et al., 2004) so, in practical terms, it would be worth to know what the suitable amount of CP should be in the cockerel's diet. If one or more essential amino acids is inadequate, the increases of amino acids will be lost as nitrogenous excretion.

Essential amino acid content, digestibility and bioavailability of amino acids in feed ingredients and suitable ratio among essential amino acids in low-protein diets may have been the reasons for the lowest level performance level of cockerels fed a lower protein diet supplemented with amino acid. In previous studies, protein, metabolizable energy, calcium requirements of Gimmizah males were determined. It has been supposed, that the nutritional requirements of the cockerels are less exacting than those of little research of females about their nutritional requirements have been made previously in Egypt. Therefore, the present study was conducted to evaluate performance of Gimmizah cockerels fed two levels of methionine and lysine and two levels of protein.

\section{MATERIALS AND METHODS}

The present study was conducted at Gimmizah Research Station, Animal Production Research Institute, Agriculture. Research. Center, Ministry of Agriculture. The purpose of the current trial was to elucidate the relationship between the dietary protein level and amino acids and to determine at which protein level, methionine and lysine are required for Gimmizah cockerels.

\section{Experimental diets and design}

The study was divided into two experiments. In each experiment thirty-six (24-weeks old) of Gimmizah cockerels allocated into 2 groups according to protein levels 12 and $13 \% \mathrm{CP}$ with two methionine levels 0.24 and 
$0.34 \%$ in $1^{\text {st }}$ experiment and with two lysine levels $(0.60$ and $0.70 \%$ ) in $2^{\text {nd }}$ experiment.The cockerels received experimental diets in a $2 \mathrm{X} 2$ factorial arrangement design for each experiment. All experimental diets were formulated to be iso-caloric (2700 ME kcal/kg diet) as shown Table 1.

Table 1. Composition and calculated analysis of the experimental diets.

\begin{tabular}{|c|c|c|c|c|c|c|c|c|}
\hline \multirow{2}{*}{ Ingredients } & \multicolumn{4}{|c|}{ Experiment 1} & \multicolumn{4}{|c|}{ Experiment 2} \\
\hline & 1 & 2 & 3 & 4 & 1 & 2 & 3 & 4 \\
\hline Yellow corn & 67.9 & 67.8 & 66.40 & 66.21 & 67.7 & 68.00 & 66.30 & 66.40 \\
\hline Soybean meal (44\% CP) & 9.10 & 9.20 & 11.90 & 11.80 & 9.10 & 9.50 & 11.80 & 11.93 \\
\hline Wheat bran & 18.30 & 18.20 & 17.11 & 17.38 & 18.51 & 17.59 & 17.40 & 17.10 \\
\hline Dicalcium phosphate. & 1.70 & 1.70 & 1.70 & 1.60 & 1.70 & 1.72 & 1.70 & 1.65 \\
\hline Limestone & 2.30 & 2.30 & 2.20 & 2.31 & 2.30 & 2.38 & 2.20 & 2.20 \\
\hline Metionine & 0.02 & 0.12 & 0.00 & 0.10 & 0.01 & 0.01 & 0.00 & 0.00 \\
\hline Lysine & 0.08 & 0.08 & 0.00 & 0.00 & 0.08 & 0.20 & 0.00 & 0.12 \\
\hline Vit. \& Min. premix* & 0.30 & 0.30 & 0.30 & 0.30 & 0.30 & 0.30 & 0.30 & 0.30 \\
\hline Salt & 0.30 & 0.30 & 0.30 & 0.30 & 0.30 & 0.30 & 0.30 & 0.30 \\
\hline Total & 100 & 100 & 100 & 100 & 100 & 100 & 100 & 100 \\
\hline \multicolumn{9}{|l|}{ Calculated analysis } \\
\hline $\mathrm{ME}$ & 2705 & 2707 & 2702 & 2700 & 2700 & 2708 & 2700 & 2710 \\
\hline $\mathrm{CP} \%$ & 12.03 & 12.10 & 12.95 & 12.99 & 12.04 & 12.10 & 12.94 & 12.96 \\
\hline $\mathrm{Ca} \%$ & 1.29 & 1.29 & 1.26 & 1.27 & 1.29 & 1.32 & 1.26 & 1.24 \\
\hline Av. ph \% & 0.47 & 0.47 & 0.47 & 0.46 & 0.47 & 0.47 & 0.47 & 0.47 \\
\hline Metionine $\%$ & 0.24 & 0.34 & 0.24 & 0.34 & 0.24 & 0.24 & 0.24 & 0.24 \\
\hline Lysine \% & 0.60 & 0.60 & 0.60 & 0.60 & 0.60 & 0.70 & 0.60 & 0.70 \\
\hline SAA & 0.47 & 0.57 & 0.47 & 0.57 & 0.46 & 0.46 & 0.48 & 0.48 \\
\hline
\end{tabular}

* Each 1 Kg of Vit. and Min. premix contains: 12000 IU Vit. A; 2500 IU vit. D3; 10 mg Vit. E; 3 mg Vit. K3; 1 mg Vit. B1; 4 mg Vit. B2; 0.02 mg Vit. B12; 3 mg Vit. B6; 40 mg Niacin; 10 mg Pantothenic acid; 1 mg Folic acid ; 0.05 mg Biotin; 500 mg Choline chloride; 10 mg Cu; 300 mg I; 75 mg Zn; 50 mg Iron; 60 mg Mn; 0.1 mg Se; 0.01 mg Cobalt.

\section{Birds' management:}

Seventy two of Gimmizah cockerels at 24 weeks of old were acclimatized for one week, during which they kept in single wire cages. Birds housed in a building with natural ventilation under regimen $16 \mathrm{hr}$ light: $8 \mathrm{hr}$ dark cycle throughout the experimental period and distributed into 8 treatments similar in average body weight ( 9 cockerels per treatment). The experimental period continued up to 40 weeks of age. Feed as mash form and water was offered $\mathrm{ad}$ libitum during the whole experimental period from 24-40 weeks of age. Initial body weight was recorded in the beginning of each experiment while; final body weight was recorded at the end of the experimental period. Body weight change was calculated by subtracting initial body weight from the final body weight. The average feed consumption of each cockerel was recorded weekly to determine protein, methionine and lysine intake.

During the experimental period cockerels were trained to produce semen samples using the abdominal massage method (Burrows\& Quinn, 1937), and these samples were used at 30, 34 and 36 weeks for artificial insemination and evaluation of semen physical traits. The ejaculate volume of semen from each cockerel was measured using a collection tube graduated in ml. To evaluate motility, a drop of diluted semen was placed on a glass slide and covered with a cover slip. While percentages of live, dead and abnormal sperms were counted by different staining techniques using eosin-nigrosen stain (Kalamah et al., 2002). Sperm motility is expressed as the percentage of active sperm with moderate to rapid progressive movement.

The semen produced by each experimental group ( 9 cockerels) was pooled and used to inseminated twice a week with a fixed volume for a group of 15 Gimmizah laying hens fed diet containing $16.5 \%$ protein and $2750 \mathrm{ME} \mathrm{kcal} / \mathrm{kg}$. After insemination with 3 days, three patches of eggs were taken at three consecutive weeks. Each of patch contained 60 eggs were collected valid for hatching for each group with a total of 480 eggs and placed in the incubator for 18 days. Eggs were candled on the $18^{\text {rd }}$ day of incubation and then calculated fertility percentage.

\section{Physiological parameters}

Blood samples were taken from each experimental group at the termination of studied period ( 5 males per treatment) into heparinized tubes. Blood plasma samples were centrifuged at $4000 \mathrm{rpm}$ for 10 minutes. Plasma concentration of total protein, albumin, glucose and transaminase enzyme activities (ALT and AST) were determined calorimetrically using commercial kits. The globulin values were calculated by subtracting the values of plasma albumin from the corresponding values of total protein (Coles, 1974).

\section{Statistical analysis:}

Data were submitted to analysis of variance using the statistical software (SPSS 2015) using the GLM (General Liner Models) procedure. In the $1^{\text {st }}$ experiment, a $2 \times 2$ factorial design was used, considering the crude protein level, Methionine level in the $1^{\text {st }}$ experiment $Y_{\mathrm{ijk}}=\mu+\mathrm{T}_{\mathrm{i}}+\mathrm{M}_{\mathrm{j}}+$ $(\mathrm{TM})_{\mathrm{ij}}+\mathrm{e}_{\mathrm{ijk}}$ and the crude protein level and lysine level in the $2^{\text {nd }}$ experiment $Y_{i j k}=\mu+T_{i}+L_{j}+(T L)_{i j}+e_{i j k}$ as the main effects, where: $Y_{\mathrm{ijk}}=$ observed trait; $\mu=$ The overall mean; $\mathrm{T}_{\mathrm{i}}=$ The effect of protein level; $\mathrm{i}=(1$ and 2$) ; \mathrm{M}_{\mathrm{j}}=$ The effect of methionine level; $\mathrm{j}=(1$ and 2$) ; \mathrm{TM}_{\mathrm{ij}}=$ Interaction between the protein and methionine levels; $\mathrm{e}_{\mathrm{ijk}}=$ Random error; in $1^{\mathrm{st}}$ experiment while, $L_{j}=$ The effect of lysine level; $j=(1$ and 2$)$; and $\mathrm{TL}_{\mathrm{ij}}=$ Interaction between the protein and lysine level in $2^{\text {nd }}$ experiment. The differences among experimental groups were tested for significant by Duncan's multiple range test (Duncan, 1955).

\section{RESULTS AND DISCUSSION}

Experiment 1:

Body weight and feed intake:

Effect of dietary protein levels:

Effect of dietary protein, methionine and their interactions on live body weight and daily feed intake, daily protein intake, methionine intake and lysine intake of Gimmizah cockerels are shown in Table 2, 5. Results revealed that there were no significant differences were observed on final BW, BW change, daily feed intake (g/bird/day), methionine intake when cockerels fed diets 
different protein content but increasing protein level in the diet from 12 to $13 \%$ displayed significantly higher values in daily protein intake $(\mathrm{P} \leq 0.01)$. These results are accordance with those reported by Alderey et al., (2017) who stated that the dietary protein levels 12 or $13 \% \mathrm{Cp}$ had not significant effects on FBW, BW change and daily feed intake but increasing protein levels from 12 to $13 \%$ had a significantly increased daily protein intake. Romero-Sanchez et al. (2007) who reported that BW of male broiler breeder was not significantly affected by feeding on 12 and $17 \%$ protein diets and added that $\mathrm{BW}$ was increased by feeding on $17 \% \mathrm{CP}$ diet during 8 to 32 wk of age, however no significant variations were subsequently noticed. In the same trend Wilson et al., (1987) observed no significant influence on body weight when fed males on protein content of the diets 12,14, 16 and $18 \%$ during period from 26 weeks until 53 weeks of age.

\section{Effect of dietary methionine levels:}

Results of dietary methionine levels for cockerels had a significant effect whereas increasing dietary methionine levels from 0.24 to $0.34 \%$ resulted in significant increases in FBW, BW change, daily feed intake and methionine intake. These results are in agreement with Harms et al. (1998) who found that feed intake of the hens increased as methionine level increasing in the diet. In the same trend Bunchasak and Silapasorn (2005) reported that methionine intake was significantly increased in parallel line with the supplemental levels increased. Austic (1986) suggested that acute dietary methionine shortage reduces the level of methionine in blood, which signals the central nervous system to activate the mechanisms responsible for feed intake reduction. In contrary Zeweil et al. (2011) studied the effect of different protein levels (12, 14 and $16 \%$ ) and methionine levels (1.673, 2.000, 2.327 and $2.754 \%$ of crude protein) on Baheij strain performance and reported that neither different protein nor methionine levels significantly influenced body weight (BW) and feed intake, it may be due to strain differences. Feed intake was increased as a result of feeding on a low protein diet, methionine concentration of $7.0 \mathrm{~g} / \mathrm{kg}$ in the diet containing 120 or $130 \mathrm{~g} \mathrm{CP} / \mathrm{kg}$ meet the methionine requirements of the cockerels. FBW had not significantly affected as a result of feeding on diets contains methionine 0.30 or $0.40 \%$. However hens fed diet containing $0.30 \%$ methionine consumed feed more than those fed on $0.40 \%$ methionine in their diets (Nofal et al., 2018).

Interactions between studied factors were significant in all traits as shown in Table 2. Cockerels fed 12\% CP-diet and $0.34 \%$ methionine gave the highest final $\mathrm{BW}$, daily feed intake and methionine intake $(2448.08,123.63$ and $0.420 \mathrm{~g}$ ), respectively than other treatment groups while, the lowest final body weight, body weight change, daily protein intake $(2376.25,252.92,0.289 \mathrm{~g})$, respectively were obtained for the cockerels fed $12 \%$ protein diet and $0.24 \%$ methionine compared with the other treatment groups.

It is notice worthy that there were no significant differences in FBW, BW change of cockerels fed diet containing $0.34 \%$ methionine with dietary protein levels (12 or $13 \%)$. Also, no significant effects was observed in feed intake and daily protein intake between cockerels fed diet containing $13 \%$ protein with any dietary methionine levels. The same trend was observed between birds fed diet containing $0.24 \%$ methionine with any protein levels.

Table 2. Effect of dietary protein, methionine levels and their interactions on live body weight and feed intake of Gimmizah cockerels.

\begin{tabular}{|c|c|c|c|c|c|c|}
\hline Treatments & Initial BW (g) & Final BW (g) & Chang in BW (g) & Daily feed intake (g) & Daily protein intake (g) & Daily M. intake (g) \\
\hline \multicolumn{7}{|l|}{ Protein levels $(\mathrm{P})$} \\
\hline P $1 \quad 12 \%$ & $2125.00 \pm 6.11$ & $2412.17 \pm 10.81$ & $287.17 \pm 11.98$ & $122.08 \pm 0.46$ & $14.70 \pm 0.05^{\mathrm{b}}$ & $0.355 \pm 0.01$ \\
\hline $13 \%$ & $2116.46 \pm 4.08$ & $2428.13 \pm 05.56$ & $311.67 \pm 05.18$ & $120.70 \pm 0.71$ & $15.63 \pm 0.09^{\mathrm{a}}$ & $0.350 \pm 0.01$ \\
\hline Sig. & NS & NS & NS & NS & $* *$ & NS \\
\hline \multicolumn{7}{|l|}{ Methionine levels } \\
\hline M $10.24 \%$ & $2120.38 \pm 05.32$ & $2396.33 \pm 08.00^{b}$ & $275.96 \pm 08.72^{b}$ & $120.35 \pm 0.39^{b}$ & $15.05 \pm 0.12$ & $0.289 \pm 0.00^{b}$ \\
\hline M $20.34 \%$ & $2121.08 \pm 05.21$ & $2443.96 \pm 06.32^{a}$ & $322.88 \pm 07.71^{\mathrm{a}}$ & $122.43 \pm 0.72^{\mathrm{a}}$ & $15.28 \pm 0.12$ & $0.416 \pm 0.00^{\mathrm{a}}$ \\
\hline Sig. & NS & $* *$ & $* *$ & $*$ & NS & $* *$ \\
\hline \multicolumn{7}{|l|}{ Interactions } \\
\hline P1X M 1 & $2123.33 \pm 9.21$ & $2376.25 \pm 11.54^{\mathrm{c}}$ & $252.92 \pm 13.02^{b}$ & $120.52 \pm 0.45^{b}$ & $14.54 \pm 0.05^{\mathrm{c}}$ & $0.289 \pm 0.001^{\mathrm{c}}$ \\
\hline P1X M 2 & $2126.67 \pm 8.41$ & $2448.08 \pm 10.02^{\mathrm{a}}$ & $321.42 \pm 14.73^{\mathrm{a}}$ & $123.63 \pm 0.49^{\mathrm{a}}$ & $14.86 \pm 0.06^{\mathrm{b}}$ & $0.420 \pm 0.001^{\mathrm{a}}$ \\
\hline $\mathrm{P} 2 \mathrm{X} \mathrm{M} 1$ & $2117.42 \pm 5.66$ & $2416.42 \pm 07.85^{b}$ & $299.00 \pm 07.21^{\mathrm{a}}$ & $120.17 \pm 0.64^{b}$ & $15.57 \pm 0.08^{a}$ & $0.288 \pm 0.001^{\mathrm{c}}$ \\
\hline $\mathrm{P} 2 \mathrm{X} \mathrm{M} 2$ & $2115.50 \pm 6.11$ & $2439.83 \pm 06.52^{a b}$ & $324.33 \pm 5.58^{\mathrm{a}}$ & $121.24 \pm 1.29^{b}$ & $15.71 \pm 0.16^{\mathrm{a}}$ & $0.412 \pm 0.001^{b}$ \\
\hline Sig. & NS & $* *$ & $* *$ & $*$ & ** & ** \\
\hline
\end{tabular}

Sig NS = not significant $*: P<0.05, * *: P<0.01)$

Semen quality and fertility

Effect of dietary protein level:

Data listed in Table (3 and 6). Dietary protein levels

had no significant effect on all semen traits; volume $(\mathrm{mm})$, motility $\%$, live sperm $\%$, dead sperm $\%$, abnormality $\%$ and fertility $\%$. However, all mentioned traits were increased numerically as a result of feeding on diet containing $12 \%$ protein than those fed $13 \%$ protein. The obtained results are in agreement with those found by Alderey et al. (2017) who stated that cockerels fed different protein levels 12\%, 13\% or $14 \%$ in the diets had no significant effects on semen volume ( $\mathrm{mm})$, motility, live sperm, dead sperm, abnormality and fertility\%. The same results were observed by Graaf $e t$ al. (2018) who fed males on 9.68, 11.7 and 13\% CP diets and found that the CP levels had no effect on the sperm concentrations and sperm motility, which is considered a more accurate measure of fertilizing potential of the sperm produced during 27-60 weeks of age. Similarly (Wilson et al., 1987) who cleared that CP levels (12, 15, and 18\%) had no significant effects on semen volume. Semen volume and sperm number of broiler breeder males were not affected by feeding on 5, 7, and 9\% CP diets, during 20 to 65 weeks of age (Buckner et al., 1986). Hocking and Bernard (1997a) indicated that semen quality of broiler breeders was better by feeding $12 \%$ CP than $16 \%$ from 21 to 66 weeks of age and further increment had no effect on sperm concentration or semen volume. No difference in semen concentration or testis weight at 65 weeks of age. (Fontana et al., 1990) reported for broiler-breeder males fed either $12 \%$ or $14 \% \mathrm{CP}$ to record either $90 \%$ or $100 \%$ of the recommended body weight target, respectively. Revington et al. (1991) reported that no variations were observed in semen volume, total 
sperm yield and sperm concentration, the proportion of males producing semen when males fed either $8 \%$ or $12 \%$ $\mathrm{CP}$. The results cleared that no differences in fertility between males fed $12 \%$ or $16 \% \mathrm{CP}$ (Hocking \&Bernard, 1997b). In contrast Hocking, 1990, reported that the broilerbreeder males fed $11 \% \mathrm{CP}$ diet had higher fertility (hatching eggs) than those that fed on $16 \% \mathrm{CP}$ diets.

\section{Effect of dietary methionine level:}

High level of methionine significantly improved fertility\% ( $\mathrm{P} \leq 0.01)$ and all studied semen traits; motility, live sperm, dead sperm, abnormality as shown in Table, 3. Increasing methionine level increase daily methionine intake and resulted in significant responses in increasing fertility percentage. These results were agreed with Nofal et al. (2018) who found that egg fertility percentage and hatchability improved as a result of feeding on methionine $0.40 \%$ in the diet than that fed on $0.30 \%$ methionine Contrary Zeweil et al. (2011) reported that fertility percentage was insignificantly affected in response to feeding on methionine levels (1.673, $2.000,2.327$ and $2.754 \%$ of crude protein) in layer diets.

The interaction between protein and methionine levels had a significant effect on fertility percentage and all semen traits; motility, live sperm, dead sperm and abnormality\%. Cockerels fed diet containing $0.34 \%$ methionine with any dietary protein levels (12 or $13 \% \mathrm{CP})$ achieved the highest values for motility, live sperm, fertility\% and the lowest values of dead sperm and abnormality\% compared with other treatment groups. From the nutritional point of using high level methionine with 12 or $13 \% \mathrm{CP}$ improved motility, live sperm, dead sperm, and abnormality and achieved the best in fertility percentage than that of low methionine level. There is no doubt that the semen quality of the cockerels is affected by many factors, such as nutrition, environmental conditions, strain, age and species, the top of these factors is the protein content of the diet, especially of amino acids. Semen production with normal sperm qualities in sufficient sperm concentration, together with the libido and mating ability ensure good reproductive performance.

The present study revealed that methionine plays a key role in maintain good sperm motility, high live sperm and fertility percentage. Insufficient methionine for Gimmizah cockerels produce sperm lack the power and ability to fertile an egg.

Table 3. Effect of dietary protein, methionine levels and their interactions on semen quality and fertility of Gimmizah cockerels.

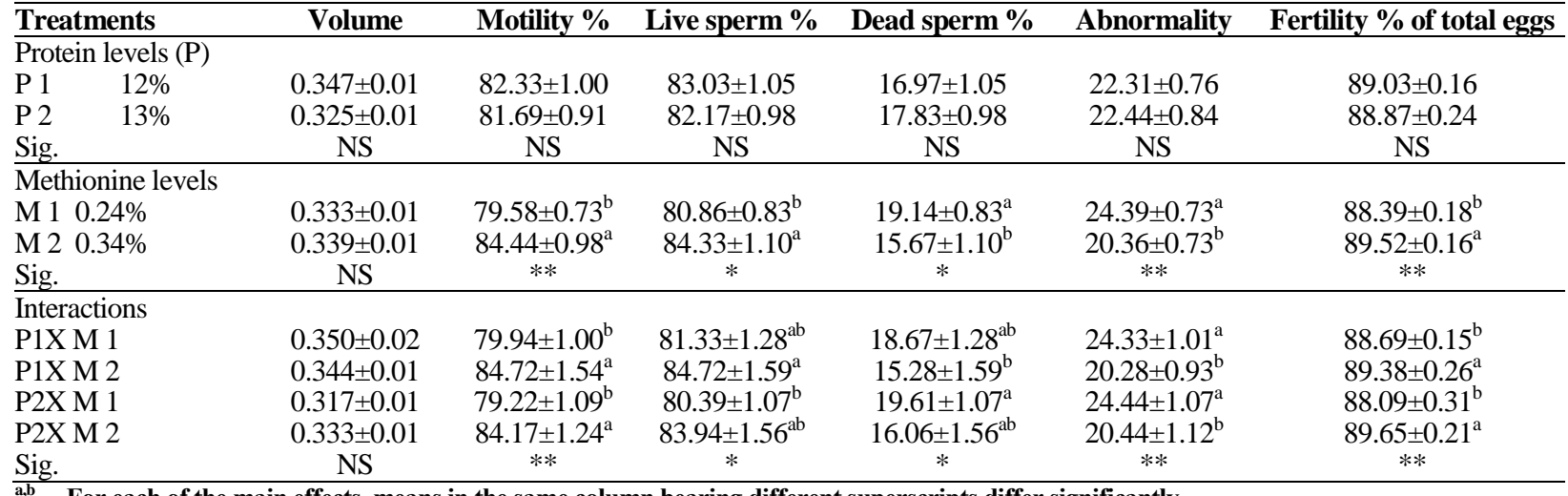

a,b....For each of the main effects, means in the same column bearing different superscripts differ significantly NS = not significant $*: \mathrm{P}<0.05, * *: \mathrm{P}<0.01)$.

There are no available researchers regarding the relation between dietary methionine levels and semen quality for cockerels.

\section{Blood constituents}

\section{Effect of dietary protein level:}

Effect of dietary protein, methionine levels and their interactions on blood constituents of Gimmizah cockerels are listed in Table 4. Results cleared that no significant

Table 4. Effect of dietary protein, methionine levels and their interactions on some blood constituents of Gimmizah cockerels.

\begin{tabular}{|c|c|c|c|c|c|c|}
\hline Treatments & Total protein $\mathrm{g} / \mathrm{dl}$ & Albumin g/dl & Globulin g/dl & Glucose mg/dl & AST (U/L) & ALT (U/L) \\
\hline \multicolumn{7}{|l|}{ Protein levels (P) } \\
\hline P $1 \quad 12 \%$ & $4.45 \pm 0.12$ & $2.25 \pm 0.13$ & $2.20 \pm 0.07^{b}$ & $125.75 \pm 1.31$ & $25.40 \pm 0.44^{\mathrm{b}}$ & $23.22 \pm 0.41$ \\
\hline $13 \%$ & $4.67 \pm 0.10$ & $2.20 \pm 0.04$ & $2.47 \pm 0.07^{\mathrm{a}}$ & $127.75 \pm 1.05$ & $27.34 \pm 0.26^{\mathrm{a}}$ & $24.61 \pm 0.58$ \\
\hline Sig. & NS & NS & $*$ & NS & $* *$ & NS \\
\hline \multicolumn{7}{|l|}{ Methionine levels } \\
\hline M $10.24 \%$ & $4.44 \pm 0.12$ & $2.24 \pm 0.10$ & $2.21 \pm 0.06^{\mathrm{b}}$ & $124.75 \pm 1.09^{\mathrm{b}}$ & $26.18 \pm 0.41$ & $23.51 \pm 0.54$ \\
\hline M $20.34 \%$ & $4.67 \pm 0.11$ & $2.20 \pm 0.09$ & $2.47 \pm 0.07^{\mathrm{a}}$ & $128.75 \pm 1.05^{\mathrm{a}}$ & $26.56 \pm 0.41$ & $24.32 \pm 0.52$ \\
\hline Sig. & NS & NS & $*$ & $*$ & NS & NS \\
\hline \multicolumn{7}{|l|}{ Interactions } \\
\hline P1X M 1 & $4.32 \pm 0.19$ & $2.25 \pm 0.21$ & $2.06 \pm 0.03^{b}$ & $123.00 \pm 1.37^{\mathrm{b}}$ & $25.50 \pm 0.60^{\mathrm{b}}$ & $22.62 \pm 0.62$ \\
\hline P1X M 2 & $4.58 \pm 0.16$ & $2.24 \pm 0.17$ & $2.35 \pm 0.12^{\mathrm{a}}$ & $128.50 \pm 1.65^{\mathrm{a}}$ & $25.30 \pm 0.71^{\mathrm{b}}$ & $23.82 \pm 0.46$ \\
\hline P2X M 1 & $4.57 \pm 0.13$ & $2.22 \pm 0.04$ & $2.35 \pm 0.10^{\mathrm{a}}$ & $126.50 \pm 1.45^{\mathrm{ab}}$ & $26.85 \pm 0.31^{\mathrm{ab}}$ & $24.40 \pm 0.77$ \\
\hline P2X M 2 & $4.77 \pm 0.15$ & $2.17 \pm 0.07$ & $2.60 \pm 0.10^{\mathrm{a}}$ & $129.00 \pm 1.46^{\mathrm{a}}$ & $27.83 \pm 0.32^{\mathrm{a}}$ & $24.83 \pm 0.93$ \\
\hline Sig. & NS & NS & $* *$ & $*$ & $* *$ & NS \\
\hline
\end{tabular}

a,b....For each of the main effects, means in the same column bearing different superscripts differ significantly NS = not significant $*: P<0.05, * *: P<0.01)$. differences in plasma total protein, albumin, glucose and ALT when fed cockerels on diets containing 12 or $13 \%-\mathrm{CP}$ diets on the other side globulin and AST were significantly increased with increasing protein levels in the diet. In agreement with the present study Alderey et al., (2017) indicated that cockerels fed $12 \%$ or $13 \%$ protein level had not significant effect on total protein, albumin glucose and ALT. 


\section{Effect of dietary methionine level:}

Regarding to methionine levels results appeared that there no significant influences in plasma total protein, albumin, AST, and ALT. Nevertheless, globulin and glucose were significantly increased by feeding on $0.34 \%$ methionine-diet.

Interaction between studied factors showed that there were significant differences $(\mathrm{P} \leq 0.01)$ among dietary treatments in globulin, glucose and AST, while plasma total protein, albumin and ALT were not affected. Cockerels fed diet containing $13 \% \mathrm{Cp}$ and $0.34 \%$ methionine recorded the highest values of plasma total protein, globulin, glucose, AST and ALT. In contrary the lowest values of globulin, glucose and ALT were obtained from cockerels fed 12\%-CP diet and $0.24 \%$ methionine Cockerels fed diet containing $13 \% \mathrm{CP}$ with $24 \%$ or $34 \%$ methionine level did not show any variations in total protein, albumin, globulin, glucose, AST and ALT levels in blood plasma. Although high protein level (13\%) with high methionine Level $(0.34 \%)$ caused to significant increases in globulin and glucose levels in blood plasma.

\section{Experiment 2:}

\section{Body weight and feed intake:}

Effect of dietary lysine level:

Dietary lysine levels had no significant effect on FBW, lysine intake was significantly increased with accompanied increasing lysine levels in the diet. (0.852 vs $0.726 \mathrm{mg})$ as shown in Table, 5. These results are consistent with those obtained by Naga Raja et al. (2017) who showed that body weight and feed intake were not influenced either by the concentration of lysine level at $(0.50,0.55,0.60,0.65$, and 0.70$)$ or by level of protein at 13.36 and $15.78 \%$ in the diet. Similarly Panda et al. (2010) observed no difference in feed intake with increasing concentration of digestible lysine $(0.60$ $0.80 \%$ ) in the diet of WL layers during 28-44 weeks of age. On the other side Gunawardana et al. (2008) reported an increase in feed intake $(109.8-113.4 \mathrm{~g} / \mathrm{b} / \mathrm{d})$ with increase in digestible lysine level (0.680-0.828\%) in brown layers during 39-52 weeks of age. It may attribute to wide range used in the study.

Statistical analysis cleared that there were no significant differences $(\mathrm{P} \leq 0.05)$ among all dietary treatments in FBW and BW change due to the interactive between the studied factors. However, highest daily feed intake was recorded by feeding on low protein and lysine level, while cockerels fed on high protein and lysine level increased daily feed intake (122.13) reflected on significant increase in daily protein and lysine intake (15.83 and 0.855 g), respectively. However there were no significant differences in daily feed intake and lysine intake of cockerels fed low CP-diet and 0.60 or $0.70 \%$ lysine.

Table 5. Effect of dietary protein, lysine levels and their interactions on live body weight and feed intake of Gimmizah cockerels.

\begin{tabular}{|c|c|c|c|c|c|c|c|}
\hline \multicolumn{2}{|c|}{ Treatments } & Initial BW (g) & Final BW (g) & Chang in BW (g) & Daily feed intake (g) & Daily protein intake (g) & Daily Lys. intake \\
\hline \multicolumn{8}{|c|}{ Protein levels $(\mathrm{P})$} \\
\hline $\mathrm{P} 1$ & $12 \%$ & $2125.00 \pm 6.11$ & $2412.17 \pm 10.81$ & $287.17 \pm 11.98$ & $122.08 \pm 0.46$ & $14.70 \pm 0.05^{\mathrm{b}}$ & $0.793 \pm 0.01$ \\
\hline $\mathrm{P} 2$ & $13 \%$ & $2116.46 \pm 4.08$ & $2428.13 \pm 05.56$ & $311.67 \pm 05.18$ & $120.70 \pm 0.71$ & $15.63 \pm 0.09^{\mathrm{a}}$ & $0.785 \pm 0.01$ \\
\hline Sig. & & NS & NS & NS & NS & $* *$ & NS \\
\hline \multicolumn{8}{|c|}{ Lysine levels (Lys) } \\
\hline Lys 1 & $0.6 \%$ & $2121.17 \pm 04.69$ & $2413.63 \pm 7.06$ & $292.46 \pm 7.06$ & $121.00 \pm 0.65$ & $15.11 \pm 0.10$ & $0.726 \pm 0.003^{\mathrm{b}}$ \\
\hline Lys 2 & $0.7 \%$ & $2120.29 \pm 05.79$ & $2426.67 \pm 9.99$ & $306.38 \pm 11.37$ & $121.78 \pm 0.58$ & $15.23 \pm 0.14$ & $0.852 \pm 0.004^{\mathrm{a}}$ \\
\hline Sig. & & NS & NS & NS & NS & NS & $* *$ \\
\hline \multicolumn{8}{|c|}{ Interactions } \\
\hline P1XLy & & $2127.83 \pm 6.69$ & $2399.83 \pm 10.58$ & $272.00 \pm 10.12$ & $122.73 \pm 0.72^{\mathrm{a}}$ & $14.76 \pm 0.09^{c}$ & $0.736 \pm 0.003^{\mathrm{b}}$ \\
\hline P1XLy & & $2122.17 \pm 11.47$ & $2424.50 \pm 18.70$ & $302.33 \pm 21.35$ & $121.43 \pm 0.54^{\mathrm{ab}}$ & $14.64 \pm 0.06^{\mathrm{c}}$ & $0.850 \pm 0.006^{\mathrm{a}}$ \\
\hline P2XLy & & $2114.50 \pm 5.77$ & $2427.42 \pm 7.87$ & $312.92 \pm 5.50$ & $119.28 \pm 0.84^{c}$ & $15.45 \pm 0.11^{\mathrm{b}}$ & $0.716 \pm 0.011^{\mathrm{c}}$ \\
\hline P2XLy & & $2118.42 \pm 5.44$ & $2428.83 \pm 8.19$ & $310.42 \pm 9.04$ & $122.13 \pm 1.03^{\mathrm{a}}$ & $15.83 \pm 0.13^{\mathrm{a}}$ & $0.855 \pm 0.006^{\mathrm{a}}$ \\
\hline Sig. & & NS & NS & NS & $*$ & $* *$ & $* *$ \\
\hline
\end{tabular}

a,b....For each of the main effects, means in the same column bearing different superscripts differ significantly

$\mathrm{NS}=$ not significant $*: \mathrm{P}<0.05, * *: \mathrm{P}<0.01)$.

Semen quality:

Effect of dietary lysine level:

Effect of dietary protein, lysine levels and their interactions on semen quality and fertility of Gimmizah cockerels are presented in Table 6 . These results showed that all semen traits were not significantly affected by feeding cockerels on dietary lysine levels. These results are in line with Obi et al. (2012) who reported that semen volume, sperm concentration and sperm quality index were similar when roosters were fed digestible lysine varying from 1000 to $550 \mathrm{mg} /$ rooster/day in DDGS based diet. The same trend was noticed by Obi et al. (2013) who found that varying levels of digestible lysine (1,000-550 mg/rooster/day) in a DDGS based diet does not had negative effects on broiler breeder male semen quality during pre-peak and peak production.

Interaction between dietary protein and lysine levels were not significant whereas neither dietary protein nor dietary lysine levels had significant effects on all semen traits. Although the best values of motility, live sperm, dead sperm and fertility were obtained when cockerels fed diet containing
$12 \% \mathrm{CP}$ with $0.6 \%$ lysine compared with other treatment groups.

\section{Blood parameters}

Effect of dietary lysine level:

According to the data given in Table 7, the results indicated that dietary lysine levels had no significant effect on plasma concentration of total protein, albumin, globulin, glucose, AST and ALT of Gimmizah cockerels.

There were significant interactions between lysine and protein levels in plasma total protein, globulin, AST and ALT $(\mathrm{P}<0.01)$, and insignificant interactions in albumin and glucose. Cockerels fed diet containing 13\%-CP and $0.70 \%$ lysine level in their diets recorded the highest values of plasma total protein, globulin, glucose, AST and ALT compared with other treatment groups. In contrast cockerels fed diet containing $12 \%-\mathrm{CP}$ and $0.60 \%$ lysine level in their diets given the lowest values of plasma total protein, globulin, glucose, AST and ALT compared with the other treatment groups. On the other hand, the highest values of total protein, globulin, AST and ALT (4.74, 2.52, 27.47 and $25.45 \mathrm{mg} / \mathrm{dl}$ ), respectively was recorded for the cockerels fed diet containing $13 \% \mathrm{CP}$ with $0.70 \%$ lysine. 
Table 6. Effect of dietary protein, lysine levels and their interactions on semen quality and fertility \% of Gimmizah cockerels.

\begin{tabular}{|c|c|c|c|c|c|c|c|}
\hline \multicolumn{2}{|c|}{ Treatments } & Volume & Motility \% & Live sperm \% & Dead sperm \% & Abnormality & Fertility \% of total eggs \\
\hline \multicolumn{8}{|c|}{ Protein levels $(\mathrm{P})$} \\
\hline P 1 & $12 \%$ & $0.347 \pm 0.01$ & $82.33 \pm 1.00$ & $83.03 \pm 1.05$ & $16.97 \pm 1.05$ & $22.31 \pm 0.76$ & $89.03 \pm 0.16$ \\
\hline $\mathrm{P} 2$ & $13 \%$ & $0.325 \pm 0.01$ & $81.69 \pm 0.91$ & $82.17 \pm 0.98$ & $17.83 \pm 0.98$ & $22.44 \pm 0.84$ & $88.87 \pm 0.24$ \\
\hline Sig. & & NS & NS & NS & NS & NS & NS \\
\hline \multicolumn{8}{|c|}{ Lysine levels (Lys) } \\
\hline Lys 1 & $0.6 \%$ & $0.339 \pm 0.01$ & $81.31 \pm 0.78$ & $81.97 \pm 0.79$ & $18.03 \pm 0.79$ & $22.17 \pm 0.67$ & $89.03 \pm 0.18$ \\
\hline Lys 2 & $0.7 \%$ & $0.333 \pm 0.01$ & $82.72 \pm 1.09$ & $83.22 \pm 1.19$ & $16.78 \pm 1.19$ & $22.58 \pm 0.91$ & $88.89 \pm 0.23$ \\
\hline Sig. & & NS & NS & NS & NS & NS & NS \\
\hline \multicolumn{8}{|c|}{ Interactions } \\
\hline P1XL & & $0.356 \pm 0.02$ & $80.94 \pm 1.08$ & $81.94 \pm 1.12$ & $18.06 \pm 1.12$ & $22.33 \pm 0.90$ & $88.94 \pm 0.21$ \\
\hline P1XL & & $0.339 \pm 0.01$ & $83.72 \pm 1.48$ & $84.11 \pm 1.76$ & $15.89 \pm 1.76$ & $22.28 \pm 1.25$ & $89.14 \pm 0.25$ \\
\hline $\mathrm{P} 2 \mathrm{XL}$ & & $0.322 \pm 0.01$ & $81.67 \pm 1.11$ & $82.00 \pm 1.14$ & $18.00 \pm 1.14$ & $22.00 \pm 1.03$ & $89.12 \pm 0.29$ \\
\hline $\mathrm{P} 2 \mathrm{XL}$ & & $0.328 \pm 0.01$ & $81.72 \pm 1.56$ & $82.33 \pm 1.63$ & $17.67 \pm 1.63$ & $22.89 \pm 1.34$ & $88.63 \pm 0.39$ \\
\hline Sig. & & NS & NS & NS & NS & NS & NS \\
\hline
\end{tabular}

a,b....For each of the main effects, means in the same column bearing different superscripts differ significantly

NS = not significant $*: \mathrm{P}<0.05, * *: \mathrm{P}<0.01)$.

Table 7. Effect of dietary protein, lysine levels and their interactions on some blood constituents of Gimmizah cockerels.

\begin{tabular}{|c|c|c|c|c|c|c|c|}
\hline \multirow{2}{*}{\multicolumn{8}{|c|}{$\frac{\text { Treatments }}{\text { Protein levels (P) }}$}} \\
\hline & & & & & & & \\
\hline P 1 & $12 \%$ & $4.45 \pm 0.12$ & $2.25 \pm 0.13$ & $2.20 \pm 0.07^{\mathrm{a}}$ & $125.75 \pm 1.31$ & $25.40 \pm 0.44^{\mathrm{b}}$ & $23.22 \pm 0.41$ \\
\hline $\mathrm{P} 2$ & $13 \%$ & $4.67 \pm 0.10$ & $2.20 \pm 0.04$ & $2.47 \pm 0.07^{\mathrm{b}}$ & $127.75 \pm 1.05$ & $27.34 \pm 0.26^{\mathrm{a}}$ & $24.61 \pm 0.58$ \\
\hline Sig. & & NS & NS & $*$ & NS & $* *$ & NS \\
\hline \multicolumn{8}{|c|}{ Lysine levels (Lys) } \\
\hline Lys 1 & $0.6 \%$ & $4.51 \pm 0.11$ & $2.20 \pm 0.10$ & $2.31 \pm 0.07$ & $126.00 \pm 1.22$ & $26.06 \pm 0.41$ & $23.26 \pm 0.36$ \\
\hline Lys 2 & $0.7 \%$ & $4.61 \pm 0.13$ & $2.24 \pm 0.10$ & $2.37 \pm 0.10$ & $127.50 \pm 1.19$ & $26.68 \pm 0.49$ & $24.57 \pm 0.62$ \\
\hline Sig. & & NS & NS & NS & NS & NS & NS \\
\hline \multicolumn{8}{|c|}{ Interactions } \\
\hline \multicolumn{2}{|c|}{ P1XLys 1} & $4.41 \pm 0.18^{c}$ & $2.22 \pm 0.19$ & $2.19 \pm 0.10^{b}$ & $125.50 \pm 1.82$ & $24.90 \pm 0.41^{\mathrm{b}}$ & $22.75 \pm 0.49^{b}$ \\
\hline \multicolumn{2}{|c|}{ P1XLys 2} & $4.48 \pm 0.19^{c}$ & $2.27 \pm 0.19$ & $2.22 \pm 0.11^{\mathrm{b}}$ & $126.00 \pm 2.07$ & $25.90 \pm 0.77^{\mathrm{ab}}$ & $23.68 \pm 0.64^{\mathrm{ab}}$ \\
\hline \multicolumn{2}{|c|}{ P2XLys 1} & $4.60 \pm 0.11^{b}$ & $2.18 \pm 0.06$ & $2.43 \pm 0.08^{\mathrm{a}}$ & $126.50 \pm 1.78$ & $27.22 \pm 0.23^{\mathrm{a}}$ & $23.78 \pm 0.48^{\mathrm{ab}}$ \\
\hline \multicolumn{2}{|c|}{ P2XLys 2} & $4.74 \pm 0.11^{\mathrm{a}}$ & $2.22 \pm 0.06$ & $2.52 \pm 0.13^{\mathrm{a}}$ & $129.00 \pm 1.03$ & $27.47 \pm 0.49^{\mathrm{a}}$ & $25.45 \pm 0.98^{\mathrm{a}}$ \\
\hline Sig. & & $* *$ & NS & $* *$ & NS & $* *$ & $*$ \\
\hline
\end{tabular}

${ }^{a, b}$....For each of the main effects, means in the same column bearing different superscripts differ significantly

NS = not significant $*: P<0.05, * *: P<0.01)$.

It can be concluded that the diets containing $13 \% \mathrm{CP}$ with $0.34 \%$ methionine or $0.60 \%$ lysine had no adverse effect on productive or reproductive performance of Gimmizah cockerels with take consideration semen quality and fertility percentage.

Generally Gimmizah cockerels require approximately $0.60 \%$ lysine or $0.34 \%$ methionine with $13 \% \mathrm{CP}$.

\section{REFERENCES}

Alderey, A. A.; H. R. Samak; A. M. E. Nasr and H. A. Abu Khashaba (2017). Nutritional requirements for Gimmizah males 1- Protein and metabolizable energy. J. Anim. Poultry Prod., Mansoura Univ. 8 (11): 435 - 442.

Austic RE. Biochemical description of nutritional effects. In: Fisher, C.; Boorman, KN. (Eds.) (1986). Nutrient requirements of poultry and nutritional research. London: Butterworths; p. 59-77.

Buckner, R. E.; J. A. Renden and T. F. Savage (1986).The effect of feeding programs on reproductive traits and selected blood chemistries of caged broiler breeder males. Poult. Sci., 65: 85-91.

Bunchasak, C. and T. Silapasorn (2005). Effects of adding Metionine in low-protein diet on production performance, reproductive organs and chemical liver composition of laying hens under tropical conditions. Int. J. of Poult. Sci., 4 (5): 301-308.

Burrows, W. H. and Quinn J. P. (1937). The collection of spermatozoa from the domestic fowl and turkey. Poult. Sci., 16, 19-24.
Chung, H. J.; L. Chung-Yi and P. Wen-ShygChiou (1998). Effects of ambient temperature and Metionine supplementation of a low protein diet on the performance of laying hens. Anim. Feed Sci. Tec., 74: 289-299.

Coles, E. H. (1974). Veterinary and Clinical Pathology. 2nd edition, PP.211-213, W.B. Saunders, Philadelphia, London, Toronto.

Duncan B. D. (1955). Multiple Range and Multiple F. Test. Biometrics, 11: 1- 42

Fontana, E. A.; Weaver Jr.; W. D. and H. P. VanKrey (1990). Effects of various feeding regimens on reproduction in broiler-breeder males. Poult. Sci., 69, 209-216.

Gunawardana, P.; D. A. Roland and M. M. Bryant (2008). Performance comparison and lysine requirements of seven commercial brown egg layer strains during phase two. Inter. J. Poult. Sci., 7 (12):1156-1162

Harms, R. H. and F. J. Ivey (1992). An evaluation of the protein and lysine requirements for broiler breeder hens' J' Appl' Res' 1:308-314'

Harms, R. H. and G. B. Russell (1995). A re-evaluation of the protein and lysine requirement for broiler breeder hens. Poultry Sci., 74 (3): 581-585.

Harms, R. H.; G. B. Russell; H. Harlow; and F. J. Ivey (1998). Performance of laying hens fed three levels of metionine in diets containing two levels of protein and energy. J. Appl. Poultry Res. 7: 45-52.

Hocking, P. M. (1990). The relationship between dietary crude protein, body weight and fertility in naturally mated broiler breeder males. Br. Poult. Sci., 31:743-757. 
Hocking, P. M. and R. Bernard (1997a). Effects of dietary crude protein content and food intake on the production of semen in two lines of broiler breeder males. Br. Poult. Sci., 38, 199-202.

Hocking, P. M. and R. Bernard (1997b). Effects of male body weight, strain and dietary protein content on fertility and musculo-skeletal disease in naturally mated broiler breeder males. Br. Poult. Sci., 38, 29-37.

Graaf, B.; M. Ciacciariello and N. C. Tyler (2018). The effect of crude protein intake on sperm quality of young and old male broiler breeders.South African J. of Animal. Sci., 48 (No. 6)

Kalamah, M. A. ; M. M. El-nady; F. A. Abdou and E. K. Esa (2002). Effect of heat stress and vitamin C on some productive traits and physiological aspects in chickens. Minufiya J. Agric. Res., 27:57-74.

Liu, Z. G. Wu; M. M. Bryant and D. A. Roland Sr. (2005). Influence of added synthetic lysine in low-protein diets with the methionine plus cysteine to lysine ratio maintained at 0.75. J. Applied Poult. Res., 14: 174-182.

Naga Raja Kumari, K.; V. Ravinder Reddy; V. ChinniPreetham; D. Srinivas Kumar; A. R Sen and S. V Rama Rao (2017). Effect of feeding different levels of lysine and protein on the performance of WLH layers. Indian J. Anim. Res., 51 (5): 901-905.

Novak, C.; H. Yakout and S. Scheideler (2004). The combined effects of dietary lysine and total sulfur amino acid level on egg production parameters and egg components in Dekalb Delta laying hens. Poult. Sci., 83: 977-984.

Nofal M. E.; H. R. Samak; A. A. Alderey and A. M. E. Nasr (2018). Effect of dietary folic acid supplementation to diets of low levels of energy and methionine of developed laying hens in summer season on performance, physiological status and immune response. J. Animal and Poultry Prod., Mansoura Univ., Vol. 9 (12): 471 - 480.
NRC, (1994). Nutrient Requirements of Poultry.9 rev. ed. National Academy Press, Washington, Dc.

Obi, C. N.; H. M. Parker; A. Corzo and C. D. McDaniel (2013). Evaluation of feeding different digestible lysine intake levels on semen characteristics and body weight of broiler breeders during pre-peak and peak production. Poult. Sci., 12 (2): 64-71.

Obi, C. N.; H. Parker; C. McDaniel and A. Corozo, (2012). Evaluation of different lysine levels on semen quality and body weight of MX males. Poult. Sci., 91: 201-201.

Panda, A. K; M. V. L. N Raju; S. V. Rama Rao; M. R. Reddy; R. N. Chatterjee and Sunder G. Shyam (2010). Effect of lysine supplementation to low protein diet and its influence on production performance, egg quality and humoral immune response of White Leghorn layers. Indian. J. Poult. Sci., 45 (3): 287-291.

Revington, W. H.; E. T. Moran and G. R. McDaniel (1991). Performance of broiler breeder males given low protein feed. Poult. Sci., 70 (1): 139-145.

Romero-Sanchez, H.; P. W. Plumstead and J. Brake (2007). Feeding broiler breeder males. 1. Effect of feeding program and dietary crude protein during rearing on body weight and fertility of broiler breeder males. Poult. Sci., 86:168-174.

Schutte, J. B.; J. de Jong and H. L. Bertram (1994). Requirement of the laying hen for sulfur amino acids.Poult. Sci., 73: 274-280.

SPSS, (2015). Statistical Package for Social Sciences Version 20.0. IBM SPSS Inc., NY, USA.

Wilson, J. L.; G. R. McDaniel and C. D. Sutton (1987). Dietary protein levels for broiler breeder males. Poult. Sci., 66:237.

Zeweil, H. S.; A. A. Abdalah; M. H. Ahmed and Marwa R. S. Ahmed (2011). Effect of different levels of protein and methionine on performance of Baheij laying hens and environmental pollution. Egypt. Poult. Sci., Vol (31) (II): (621-639).

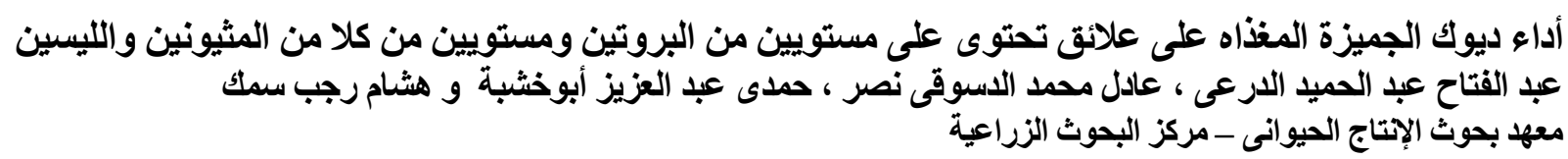

استخدم فى هذه الدر اسة 72 ديك من سلالة الجميزة عند 24 أسبوع من العمر لتقييم أداء ديوك الجميزة المغذاه على علائق تحتوى على مستويين من البروتين ومستويين

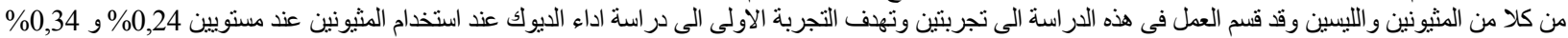

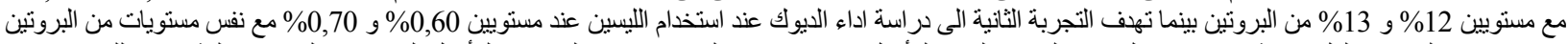

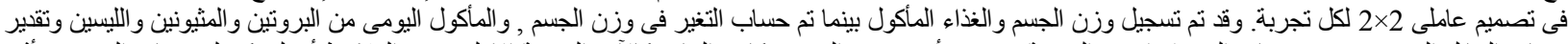

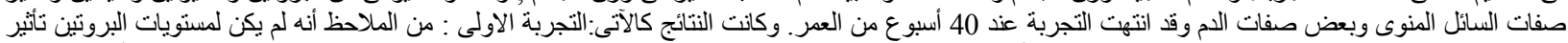

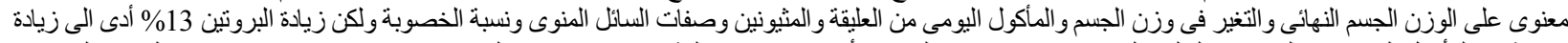

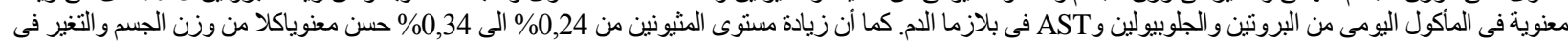

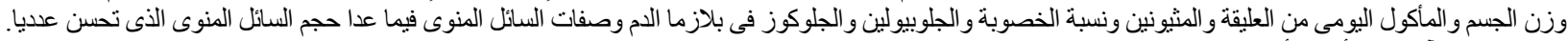

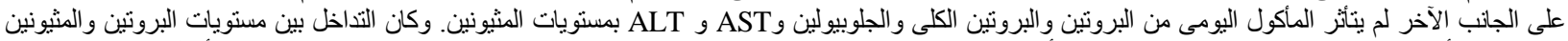

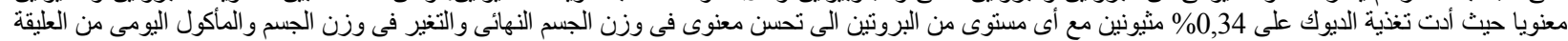

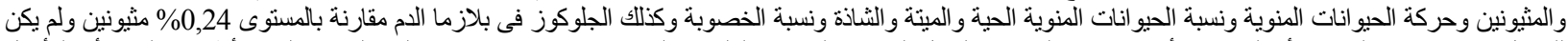

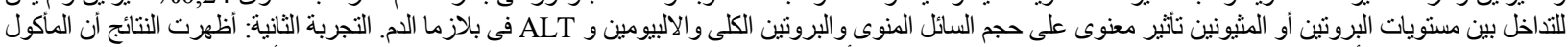

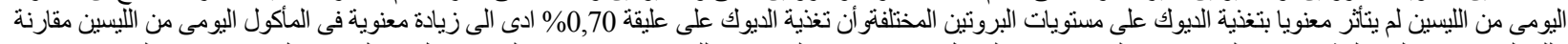

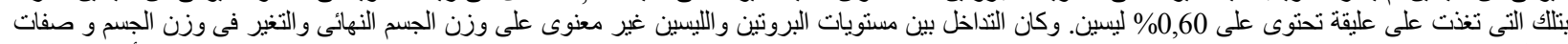

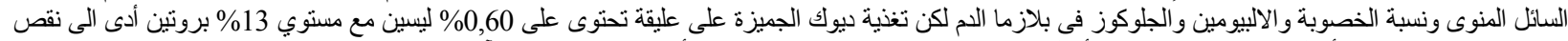

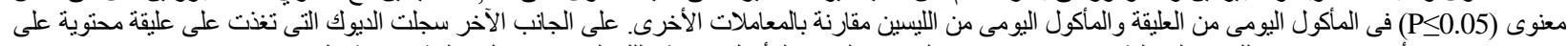

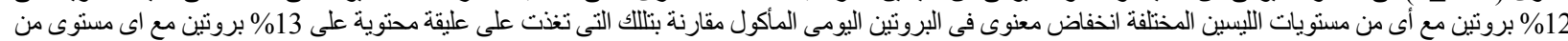

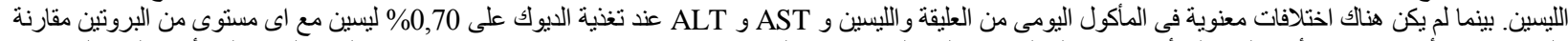

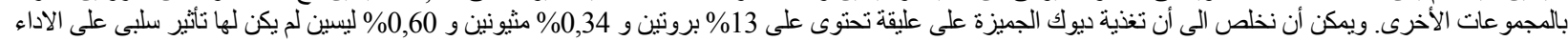
الانتاجى و التتاسلى مع الاخذ فى الاعتبار نسبة الخصوبة أنى وجودة السائل المنوى. 